\title{
ANALYSIS OF HEAVY METALS CONTAMINATION IN BOTTOM SEDIMENTS OF LAKES LOCATED IN THE GNIEZNO LAKELAND
}

\author{
Mariusz Sojka ${ }^{\bowtie}$, Joanna Jaskuła, Rafał Wróżyński \\ Institute of Land Improvement, Environment Development and Geodesy, Poznań University of Life Sciences, Piątkowska 94 , \\ 60-649 Poznań
}

\begin{abstract}
Aim of the study

The aim of the study was to assess the degree of heavy metal pollution in bottom sediments of lakes on the basis of geochemical and ecotoxicological indicators.
\end{abstract}

\begin{abstract}
Material and methods
The analysis was conducted for 16 lakes located in the Gniezno Lakeland in central-western Poland. The studied lakes were included in the research program obtained from the Inspector of Environmental Protection within the framework of the State Environmental Monitoring. The Contamination Factor (CF), Pollution Load Index (PLI) and Metal Pollution Index (MPI) were calculated to assess the level of sediment contamination. Assessment of the potential toxic effects of heavy metals accumulated in bottom sediments were made on the basis of TEC, MEC and PEC values. Cluster analysis (CA) was used to show similarities between lakes in terms of heavy metal concentration in bottom sediments. To identify factors affecting metal content in bottom sediments and potential sources of pollution, the PCA analysis was applied.
\end{abstract}

\section{Results and conclusions}

The analyses showed a large variation of heavy metals concentration in bottom sediments. The bottom sediments of lakes were polluted mostly with lead. High concentrations of lead in individual lakes may cause harm to living organisms. The lowest concentrations of heavy metals were found in the bottom sediments of Kamienieckie Lake and the highest in Ostrówieckie Lake. Cluster analysis allowed to divide the lakes into two groups with similar concentration of heavy metal in bottom sediments. The studies did not allow to clearly expose the factors responsible for determining the heavy metal content in bottom sediments of lakes.

Keywords: pollution, bottom sediments, lake, ecotoxicity, geochemical indices

\section{INTRODUCTION}

Research on heavy metal content in the aquatic environment has been widely carried out from many years by various scientific centres and laboratories around the world as part of national environmen- tal monitoring programs (Szyczewski et al., 2009). Great interest is associated with the bioaccumulation of heavy metals and a possible negative impact on living organisms, even at low concentrations. Heavy metals can be found in surface waters due to the geological structure, relief and climatic conditions that

凶e-mail: mariusz.sojka@up.poznan.pl 
shape the rate of geochemical processes. Over the last century, there have been drastic changes in the natural environment. The transformation of the land use structure has accelerated the circulation of matter, including an increase in sedimentation and pollution in lakes. A large part of heavy metals is supplied to water by anthropogenic sources, i.e. points of municipal and industrial sewage discharge, mine waters and surface runoff from agricultural and urbanized areas (Borek, 2018; Dąbrowska et al., 2016; Sojka et al., 2016). Heavy metal transport is associated with the presence of silty and clay fractions in river waters, and with the content of organic matter (Frankowski et al., 2009). Heavy metals with debris are carried in the aquatic environment, and sediment under favourable hydrodynamic conditions (Sojka et al., 2018a). Research show that heavy metal concentrations in the bottom sediments of rivers are generally lower than in the bottom sediments of the reservoirs (Soj$\mathrm{ka}$ et al., 2018b). Their concentrations in the bottom sediments of reservoirs depend on the characteristics of pollution sources, while spatial variability is connected to the hydraulic conditions and the content of organic matter in the sediments as well as to silty and clay fractions (Sojka et al., 2013). Heavy metals in the bottom sediments provide good evidence of the anthropopressure impact on lakes and aquatic ecosystems. Their concentrations in bottom sediments are particularly important for studying long-term effects. Heavy metals are responsible for a specific type of pollution, because they are not biodegradable, but instead accumulate in various elements of aquatic ecosystems (Glińska-Lewczuk et al., 2009). Assessment of the pollution degree of bottom sediments with heavy metals is most often performed in reference to the values of the geochemical background (Zhou et al. 2019). These, however, are used to calculate geochemical indicators, e.g. Geo-accumulation Index (Igeo), Enrichment Factor (EF), Pollution Load Index (PLI), Sediment Pollution Index (SPI) and Sediment Metal Enrichment Index (SEF). These indicators allow assessment of pollution or comparison of bottom sediment pollution between reservoirs (Dung et al., 2013). Values of indicators of bottom sediment pollution help answering the questions: what is the impact of anthropogenic activities on a lake? What is bottom sediment pollution? What is the potential ecological threat? (Raut et al., 2017; Yang, 2018). The identification of heavy metal sources in bottom sediments is particularly difficult due to the overlapping of various sources mainly of anthropogenic origin (Karthikeyan et al., 2018; Sojka et al., 2019a; Sojka et al., 2019b). Frequently, identification of pollution sources is performed indirectly by statistical methods that highlight the share of individual pollution sources supplying heavy metals to lakes (Kumar et al., 2019; Siepak and Sojka, 2017; Sojka et al., 2008, Wiatkowska, 2019).

The aim of the study was: (1) assessment of bottom sediment pollution by heavy metals $(\mathrm{Cr}, \mathrm{Ni}, \mathrm{Cu}$, $\mathrm{Zn}, \mathrm{Cd}$ and $\mathrm{Pb}$ ) in lakes, (2) determination of potential toxic effects of heavy metals on living organisms, (3) indication of similarities and differences in heavy metal content in bottom sediments of lakes and (4) determination of factors affecting heavy metal content in bottom sediments.

\section{MATERIALS AND METHODS}

\section{Location and characteristics of lakes and catchments}

The research was carried out for 16 lakes located in the Gniezno Lakeland (see: Fig. 1). The area of individual lakes ranges from 37.4 ha (Kamienieckie) to 550.9 ha (Niedzieggiel), while the volume ranges from 687 thou. $\mathrm{m}^{3}$ (Kamienieckie) to 38239.5 thou. $\mathrm{m}^{3}$ (Popielewskie) (see: Table 1). The average depth varies from $1.8 \mathrm{~m}$ (Kamienieckie) to $12.4 \mathrm{~m}$ (Popielewskie). The length of shorelines is very diverse and ranges from $2.29 \mathrm{~km}$ (Lednica) to $26.68 \mathrm{~km}$ (Popielewskie), while the shoreline development index is between 1.2 (Żnińskie Duży) and 4.3 (Popielewskie). The minimum value of exposure index is 6 (Fołuskie), and the maximum is 100.2 (Niedzięgiel).

The catchment area of the studied lakes is diverse. For example, Szydłowski Lake supplying the smallest area and has only $20.9 \mathrm{~km}^{2}$, the largest supply area belongs to Lake Rogoźno with about $690.9 \mathrm{~km}^{2}$ (see: Table 2). The average catchment heights are between 87.7 and $117.5 \mathrm{~m}$ a.s.l. The catchment areas are relatively homogenous. At the Lednica, Ostrowski, Starski and Wilczyński lake catchments, the mean slopes are the lowest (about 1\%), while in the Popielewskie 


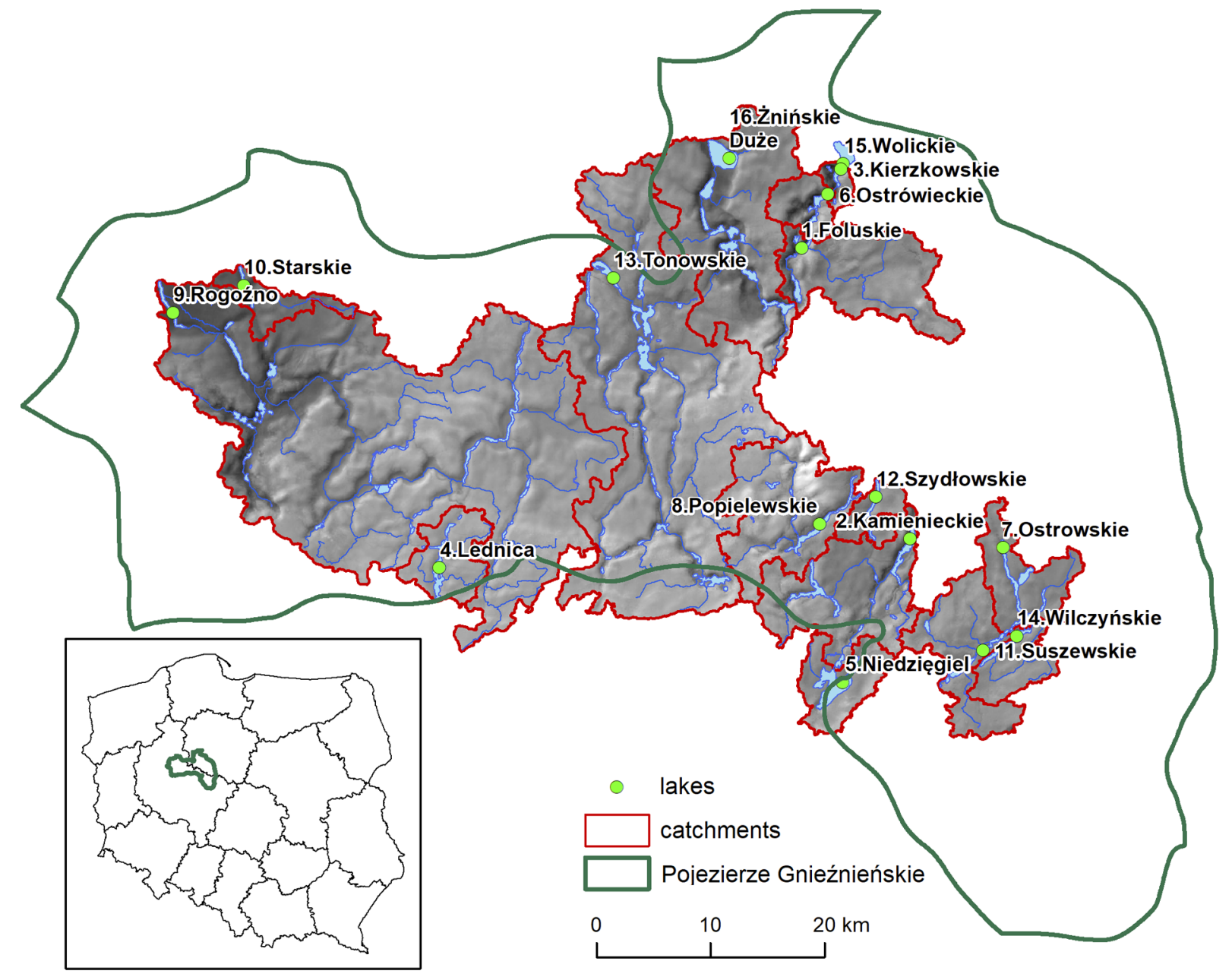

Fig. 1. Lakes location in the Gniezno Lakeland

Lake catchment the mean slope is the highest (about $2.2 \%)$. In terms of the use structure, arable lands cover between $55.5 \%$ and $93.6 \%$ of the catchments. Exception is Niedzieggiel Lake, where only $32,1 \%$ of catchment area is arable. Also, forests cover a diverse share of the catchments, from $0 \%$ in Szydłowski Lake up to $38,1 \%$ in Niedzięgiel Lake. In the catchment areas of Ostrowski, Tonowski, Wilczyński and Żniński Duży lakes, the share of built-up areas is above $5 \%$, while in the catchments of Szydłowski and Starskie lakes it does not exceed $1 \%$. Besides the built-up areas comprising a large part of the Wilczyński Lake catchment, but also its density of road network is the highest. The catchment of Starskie Lake is characterized by the lowest road network density. Whereas, the Niedziegiel Lake catchment has the highest share of forests, meadows and surface waters. The least meadows were found in the Szydłowski Lake catchment, while the least surface waters in the Foluskie Lake catchment area. The density of river network, which indirectly describes soil permeability, is varied and ranges from 0.75 to $1.85 \mathrm{~km}^{2}$. The most intense water exchange occurs in Kamienieckie Lake over 21 times a year, while the least frequent water exchange occurs in Szydłowski Lake - on average once every eight years. 
Table 1. Basic parameters of the lakes

\begin{tabular}{|c|c|c|c|c|c|c|c|c|c|c|c|}
\hline $\mathrm{Nr}$ & Lake & $\mathrm{X}$ & $\mathrm{Y}$ & $\begin{array}{l}\text { LA } \\
{[\mathrm{ha}]}\end{array}$ & $\begin{array}{c}\mathrm{V} \\
{\left[\text { tys.m }{ }^{3}\right]}\end{array}$ & $\begin{array}{l}\mathrm{MD} \\
{[\mathrm{m}]}\end{array}$ & $\begin{array}{c}\mathrm{L} \\
{[\mathrm{m}]}\end{array}$ & $\begin{array}{l}\mathrm{W} \\
{[\mathrm{m}]}\end{array}$ & $\mathrm{SL}[\mathrm{m}]$ & $\begin{array}{l}\mathrm{SD} \\
{[-]}\end{array}$ & $\begin{array}{l}\text { EI } \\
{[-]}\end{array}$ \\
\hline 1 & Foluskie & $52^{\circ} 47^{\prime} 31^{\prime \prime}$ & $17^{\circ} 50^{\prime} 29^{\prime \prime}$ & 62.4 & 6520.3 & 10.4 & 1705 & 450 & 4650 & 1.7 & 6.0 \\
\hline 2 & Kamienieckie & $52^{\circ} 33^{\prime} 10^{\prime \prime}$ & $17^{\circ} 58^{\prime} 39^{\prime \prime}$ & 37.4 & 687.0 & 1.8 & 1700 & 410 & 4325 & 2.0 & 20.8 \\
\hline 3 & Kierzkowskie & $52^{\circ} 50^{\prime} 57^{\prime \prime}$ & $17^{\circ} 53^{\prime} 7^{\prime \prime}$ & 77.3 & 6195.3 & 8.0 & 2100 & 530 & 5150 & 1.7 & 9.7 \\
\hline 4 & Lednica & $52^{\circ} 32^{\prime} 9^{\prime \prime}$ & $17^{\circ} 22^{\prime} 42^{\prime \prime}$ & 339.1 & 24397.1 & 7.0 & 7300 & 825 & 2290 & 3.4 & 48.4 \\
\hline 5 & Niedzięgiel & $52^{\circ} 26^{\prime} 51^{\prime \prime}$ & $17^{\circ} 53^{\prime} 22^{\prime \prime}$ & 550.9 & 30089.9 & 5.5 & 5920 & 1450 & 24280 & 2.9 & 100.2 \\
\hline 6 & Ostrowskie & $52^{\circ} 32^{\prime} 5^{\prime \prime}$ & $18^{\circ} 7^{\prime} 20^{\prime \prime}$ & 314.5 & 31242.9 & 9.9 & 6800 & 1080 & 19925 & 3.2 & 31.8 \\
\hline 7 & Ostrowickie & $52^{\circ} 49^{\prime} 28^{\prime \prime}$ & $17^{\circ} 51 ’ 34^{\prime \prime}$ & 276.7 & 22987.0 & 8.3 & 6255 & 1190 & 21625 & 3.6 & 33.3 \\
\hline 8 & Popielewskie & $52^{\circ} 34^{\prime} 31^{\prime \prime}$ & $17^{\circ} 52^{\prime} 16^{\prime \prime}$ & 308.5 & 38239.5 & 12.4 & 10000 & 620 & 26680 & 4.3 & 24.9 \\
\hline 9 & Rogoźno & $52^{\circ} 44^{\prime} 3^{\prime \prime}$ & $17^{\circ} 1 ’ 9 ”$ & 125.8 & 3808.5 & 3.0 & 5100 & 350 & 10925 & 2.8 & 41.9 \\
\hline 10 & Starskie & $52^{\circ} 45^{\prime} 24^{\prime \prime}$ & $17^{\circ} 6^{\prime} 53^{\prime \prime}$ & 67.5 & 3809.8 & 5.6 & 2460 & 480 & 5800 & 2.0 & 12.1 \\
\hline 11 & Suszewskie & $52^{\circ} 28^{\prime} 52^{\prime \prime}$ & $18^{\circ} 5^{\prime} 28^{\prime \prime}$ & 81.7 & 5325.7 & 6.5 & 3080 & 430 & 7900 & 2.5 & 12.6 \\
\hline 12 & Szydłowskie & $52^{\circ} 35^{\prime} 10^{\prime \prime}$ & $17^{\circ} 56^{\prime} 13^{\prime \prime}$ & 140.2 & 15883.9 & 11.3 & 5000 & 300 & 12425 & 3.0 & 12.4 \\
\hline 13 & Tonowskie & $52^{\circ} 46^{\prime} 9^{\prime \prime}$ & $17^{\circ} 35^{\prime} 9^{\prime \prime}$ & 159.9 & 3189.9 & 1.9 & 3900 & 750 & 10175 & 2.2 & 84.2 \\
\hline 14 & Wilczyńskie & $52^{\circ} 28^{\prime} 50^{\prime \prime}$ & $18^{\circ} 6^{\prime} 41^{\prime \prime}$ & 173.8 & 12615.4 & 7.3 & 5700 & 520 & 13200 & 2.8 & 23.8 \\
\hline 15 & Wolickie & $52^{\circ} 51^{\prime} 57^{\prime \prime}$ & $17^{\circ} 53^{\prime} 34^{\prime \prime}$ & 243.5 & 11888.9 & 4.9 & 2450 & 1350 & 6950 & 1.3 & 49.7 \\
\hline 16 & Żnińskie Duże & $52^{\circ} 51^{\prime} 46^{\prime \prime}$ & $17^{\circ} 43^{\prime} 60^{\prime \prime}$ & 431.6 & 29492.6 & 6.8 & 3250 & 1865 & 8500 & 1.2 & 63.5 \\
\hline
\end{tabular}

\section{DATA AND SOURCE MATERIALS}

The study uses the results of research on the content of $\mathrm{Cr}, \mathrm{Ni}, \mathrm{Cu}, \mathrm{Zn}, \mathrm{Cd}$ and $\mathrm{Pb}$ in bottom sediments of lakes, conducted as part of the State Environmental Monitoring (GIOŚ, 2016). A 5-centimeter surface layer of sediments was collected with a van Veen sampler for testing. One sample was taken from lakes with an area of less than 250 ha, from lakes with an area of 250 to 500 ha -2 samples, and 3 samples from lakes with an area of 500 to 1000 ha. So-called averaged samples were prepared for sampling from several points (GIOŚ, 2016). Cr, Ni, Cu, Zn, Cd and $\mathrm{Pb}$ were determined by atomic emission spectrometry with inductively coupled plasma excitation (ICP-OES) in accordance with PN-EN ISO 11885: 2009.

The parameters of each lake were measured on the basis of the Atlas of Polish Lakes (Jańczak 1996), taking into account the basic characteristics: lake area (LA), volume (V), mean depth (MD), width (W), length (L), shoreline length (SL), shoreline development indicator (SD) and exposure index (EI). In addition, a total catchment area was specified for the lakes on the ba- sis of the Raster Hydrographic Map of Poland made available by the Polish National Water Management. Numerical terrain models (NMT) were developed for the catchments on the basis of altitude data with a grid interval of at least $100 \mathrm{~m}$ provided by the Head Office of Geodesy and Cartography (GUGIK). On the basis of the NMT, the basic physiographic characteristics of catchments were determined, i.e. height differences, maximum, minimum and mean height $(\mathrm{MH})$ and mean slope (MS). The structure of land cover for individual catchments was determined on the basis of data contained in the General Geographic Database (BDOO). The following land cover classes have been distinguished: arable land (AL), forests (F), built-up areas (BA), meadows and pastures (G), surface waters (SW). In addition, river density (RiD) and road network (RoS) was calculated, as well as the number of intersection points of road and river network (RRI). For each of the lakes, the water exchange rate (WEI) was measured as the quotient of outflow from the catchment and the lake volume (see: Table 2). Outflows from a catchment were determined on the basis of a map of average unit outflows from Poland. 
Table 2. Basic parameters of basins with water exchange index of the lakes

\begin{tabular}{|c|c|c|c|c|c|c|c|c|c|c|c|c|c|}
\hline $\mathrm{Nr}$ & $\begin{array}{c}\text { Jezioro } \\
\text { Lake }\end{array}$ & $\begin{array}{c}\mathrm{A} \\
{\left[\mathrm{km}^{2}\right]}\end{array}$ & $\begin{array}{c}\mathrm{MH} \\
\text { [m.a.s.l] }\end{array}$ & $\begin{array}{l}\text { MS } \\
{[\%]}\end{array}$ & $\begin{array}{c}\text { RiD } \\
{\left[\mathrm{km} / \mathrm{km}^{2}\right]}\end{array}$ & $\begin{array}{c}\text { RoS } \\
{\left[\mathrm{km} / \mathrm{km}^{2}\right]}\end{array}$ & $\begin{array}{c}\text { RRI } \\
{[-]}\end{array}$ & $\begin{array}{l}\mathrm{AL} \\
{[\%]}\end{array}$ & $\begin{array}{c}\mathrm{F} \\
{[\%]}\end{array}$ & $\begin{array}{l}\text { BA } \\
{[\%]}\end{array}$ & $\begin{array}{c}\mathrm{G} \\
{[\%]}\end{array}$ & $\begin{array}{l}\text { SW } \\
{[\%]}\end{array}$ & $\begin{array}{l}\text { WEI } \\
{[-]}\end{array}$ \\
\hline 1 & Foluskie & 96.2 & 104.4 & 1.6 & 0.89 & 0.69 & 31 & 69.8 & 24.1 & 3.3 & 0.9 & 1.9 & 1.40 \\
\hline 2 & Kamienieckie & 155.0 & 106.4 & 1.6 & 1.22 & 0.91 & 54 & 55.5 & 29.6 & 1.4 & 5.6 & 7.9 & 21.35 \\
\hline 3 & Kierzkowskie & 130.0 & 102.2 & 1.9 & 0.82 & 0.71 & 37 & 66.1 & 25.6 & 3.4 & 1.8 & 3.1 & 1.99 \\
\hline 4 & Lednica & 43.1 & 115.7 & 1.0 & 1.48 & 0.77 & 24 & 80.3 & 7.0 & 3.1 & 1.4 & 8.2 & 0.17 \\
\hline 5 & Niedzięgiel & 42.2 & 108.7 & 1.1 & 0.97 & 0.8 & 11 & 32.1 & 38.1 & 2.6 & 12.4 & 14.8 & 0.13 \\
\hline 6 & Ostrowskie & 154.3 & 105.8 & 1.0 & 1.53 & 0.98 & 35 & 59.7 & 26 & 5.9 & 2.8 & 5.6 & 0.47 \\
\hline 7 & Ostrowickie & 121.5 & 102.9 & 1.8 & 0.81 & 0.71 & 83 & 65.7 & 26.5 & 3.6 & 1.4 & 2.8 & 0.50 \\
\hline 8 & Popielewskie & 110.8 & 117.5 & 2.2 & 1.67 & 0.99 & 65 & 71.3 & 15.1 & 4.1 & 6.4 & 3.1 & 0.27 \\
\hline 9 & Rogoźno & 690.9 & 104.6 & 1.3 & 1.66 & 0.82 & 344 & 71 & 21.1 & 2.7 & 3.2 & 2 & 17.16 \\
\hline 10 & Starskie & 25.7 & 87.7 & 1.0 & 1.82 & 0.65 & 11 & 66.6 & 27 & 0.9 & 3.1 & 2.4 & 0.64 \\
\hline 11 & Suszewskie & 70.2 & 107.7 & 1.1 & 1.69 & 1.08 & 44 & 74.2 & 13.4 & 4.7 & 3.8 & 3.9 & 1.25 \\
\hline 12 & Szydłowskie & 20.9 & 103.9 & 1.2 & 0.75 & 0.89 & 11 & 93.6 & 0 & 0.3 & 0 & 6.1 & 0.12 \\
\hline 13 & Tonowskie & 458.8 & 110.5 & 1.4 & 1.42 & 0.83 & 146 & 64.2 & 22 & 6 & 4.7 & 3.1 & 13.61 \\
\hline 14 & Wilczyńskie & 32.6 & 105.9 & 1.0 & 1.85 & 1.28 & 20 & 73 & 9.6 & 10.5 & 2.1 & 4.8 & 0.24 \\
\hline 15 & Wolickie & 130.0 & 102.2 & 1.9 & 0.82 & 0.71 & 37 & 66.1 & 25.6 & 3.4 & 1.8 & 3.1 & 1.03 \\
\hline 16 & Żnińskie Duże & 184.3 & 99.0 & 1.5 & 0.81 & 0.76 & 46 & 73.4 & 11.6 & 5.7 & 2.8 & 6.5 & 0.59 \\
\hline
\end{tabular}

\section{INDICATORS FOR THE DEGREE OF BOTTOM SEDIMENT POLLUTION}

To assess the degree of bottom sediment pollution, the Contamination Factor (CF), Pollution Load Index (PLI) and Metal Pollution Index (MPI) were calculated for individual metals (Jahan and Strezov, 2018; Raut et al., 2017; Sojka et al., 2019a; Yang, 2018). The CF index was proposed by Martin and Meybeck (1979):

$$
C F_{i}=\frac{C_{i}}{B_{i}}
$$

where:

$C_{i}$ - concentration of the analyzed heavy metal in the bottom sediments $\left[\mathrm{mg} \cdot \mathrm{kg}^{-1}\right]$,

$B_{i}$ - geochemical background of the analyzed heavy metal $\left[\mathrm{mg} \cdot \mathrm{kg}^{-1}\right]$.

The following geochemical background values were adopted: $\mathrm{Cd}-0.5 \mathrm{mg} \cdot \mathrm{kg}^{-1}, \mathrm{Cu}-6 \mathrm{mg} \cdot \mathrm{kg}^{-1}, \mathrm{Cr}$ $-5 \mathrm{mg} \cdot \mathrm{kg}^{-1}, \mathrm{Ni}-5 \mathrm{mg} \cdot \mathrm{kg}^{-1}, \mathrm{~Pb}-10 \mathrm{mg} \cdot \mathrm{kg}^{-1}$ and $\mathrm{Zn}$
- $48 \mathrm{mg} \cdot \mathrm{kg}^{-1}$ (Bojakowska and Sokołowska, 1998). The CF index makes it possible to assess the bottom sediment pollution individually for each element. The $\mathrm{CF}$ index values allowed the classification of the conditions of bottom sediment pollution into one of four classes: low contaminated $(\mathrm{CF}<1)$, medium contaminated $(1 \leq \mathrm{CF}<3)$, significantly contaminated $(3 \leq \mathrm{CF}$ $<6)$ and very contaminated $(\mathrm{CF} \leq 6)$.

Total heavy metal contamination of bottom sediments was assessed using the PLI index proposed by Tomilson et al. (1980) and Jahan and Strezov (2018):

$P L I=\left(C F_{1} \cdot C F_{2} \cdot \ldots \cdot C F_{i}\right)^{\frac{1}{i}} P L I=\left(\frac{C_{n 1}}{B_{n 1}} \cdot \frac{C_{n 2}}{B_{n 2}} \cdot \ldots \cdot \frac{C_{n i}}{B_{n i}}\right)^{\frac{1}{i}}$

where:

$i$ - number of analyzed heavy metals,

$C F_{i}$ - pollution index for the analyzed heavy metal (calculated according to the formula above). 
On the basis of the PLI values, the heavy metal bottom sediment pollution can be assigned to uncontaminated $(\mathrm{PLI} \leq 1)$ or contaminated $(\mathrm{PLI}>1)$ class.

Limitations and difficulties of statistical analysis for indexes determining individual metal contaminations were followed by the development of multi-metal indexes. Metal Pollution Index (MPI) was calculated in order to compare total content of heavy metals among the lakes. The MPI is a commonly used index for assessing pollution, including soils and bottom sediments (Joksimovic et al., 2019; Singovszka et al., 2017). The MPI was calculated as follows:

$$
M P I=\left(C_{1} \cdot C_{2} \cdot \ldots \cdot C_{i}\right)^{\frac{1}{i}} M P I=\left(C_{n 1} \cdot C_{n 2} \cdot \ldots \cdot C_{n i}\right)^{\frac{1}{i}}
$$

where:

$$
\begin{aligned}
& C_{i}-\begin{array}{l}
\text { concentration of the analyzed heavy metal in } \\
\text { bottom sediments }\left[\mathrm{mg} \cdot \mathrm{kg}^{-1}\right],
\end{array} \\
& i-\text { number of analyzed heavy metals. }
\end{aligned}
$$

\section{Ecotoxicological indices}

The study adopts ecotoxicological criteria, which were applied to the assessment of the effect of heavy metal pollution on aquatic organisms. The evaluation of the potential toxic impact of heavy metals accumulated in bottom sediments was performed on the basis of TEC, MEC and PEC values (MacDonald et al., 2000b). The Threshold Effect Concentration (TEC) value is defined as the limit value below which there are no harmful effects on benthic organisms, whereas Probable Effect Concentration (PEC) is a value which if exceeded leads to toxicosis of benthic organisms. Midpoint Effects Concentrations (MEC) is the mean value between the TEC and PEC limits. Based on the method developed by MacDonald et al. (2000a), four levels of sediment pollution and their impact on living organisms have been distinguished: I ( $\leq$ TEC), II ( $>$ TEC $\leq$ MEC), III ( $>$ MEC $\leq$ PEC), IV ( $>$ PEC). According to the adopted methodology, sediments classified as level I, II, III $(\leq$ PEC) can cause occasional harm to organisms, while sediments at level IV (> PEC) are often followed by symptoms of toxicosis. It is assumed that the sediment is classified as harmful to living organisms when the PEC exceeds in at least one tested heavy metal (see: Table 3 ).
Table 3. Ecotoxicological criteria for assessing the quality of lake bottom sediments using the TEC, MEC and PEC values $\left(\mathrm{mg} \cdot \mathrm{kg}^{-1}\right)$

\begin{tabular}{ccccc}
\hline & \multicolumn{4}{c}{ TEC, MEC, PEC } \\
\cline { 2 - 5 } Heavy \\
metals & $\begin{array}{c}\text { level I } \\
(\leq \text { TEC) }\end{array}$ & $\begin{array}{c}\text { level II } \\
(>\text { TEC } \leq \\
\text { MEC) }\end{array}$ & $\begin{array}{c}\text { level III } \\
(>\text { MEC } \leq \\
\text { PEC) }\end{array}$ & $\begin{array}{c}\text { level IV } \\
(>\text { PEC) }\end{array}$ \\
\hline $\mathbf{C r}$ & $\leq 43$ & $43-76.5$ & $76.5-110$ & $>110$ \\
\hline $\mathbf{N i}$ & $\leq 23$ & $23-36$ & $36-49$ & $>49$ \\
\hline $\mathbf{C u}$ & $\leq 32$ & $32-91$ & $91-150$ & $>150$ \\
\hline $\mathbf{Z n}$ & $\leq 120$ & $120-290$ & $290-460$ & $>460$ \\
\hline $\mathbf{C d}$ & $\leq 0,99$ & $0.99-3.0$ & $3.0-5.0$ & $>5,0$ \\
\hline $\mathbf{P b}$ & $\leq 36$ & $3636-83$ & $83-130$ & $>130$ \\
\hline
\end{tabular}

\section{STATISTICAL ANALYSIS}

In order to present the general characteristics of heavy metal pollution of bottom sediments of lakes in the Gniezno Lakeland, basic statistics were analyzed, i.e. minimum, maximum, average, median values and coefficients of variation. The statistical analysis was carried out on the basis of 16 values for each of the heavy metals. The division of lakes into groups characterized by similar content of heavy metals in bottom sediments was made by cluster analysis (CA). Grouping was done by the Ward method, and the square of Euclidean distance was used as a measure of similarity. For the division into groups, the criteria proposed by Ptak et al. (2018) were applied. The significance of differences in the heavy metal content in these groups was evaluated using the non-parametric Mann-Whitney $\mathrm{U}$ test. The principal component analysis (PCA) was conducted to determine the potential sources of heavy metals in bottom sediments. The PCA analysis was carried out in relation to the morphometric parameters of the lakes and hydrological conditions the coefficient of water exchange intensity in a lake, physiographic characteristics of a catchment and the catchment usage. The following morphometric parameters of the lakes (AL - area of lake; V - volume, $\mathrm{MD}$ - mean depth; SD - shoreline development index and EI - exposure indicator), water exchange intensity index in lakes (WEI) and catchment parameters were taken into account during the analysis $(\mathrm{A}-$ catchment area; $\mathrm{MH}$ - mean catchment height; $\mathrm{MS}$ - mean slope 
in catchment; RiD - river network density; RoS - road network density; $\mathrm{AL}$ - share of arable land; $\mathrm{F}$ - share of forests; BA - share of built-up areas; $\mathrm{G}$ - share of meadows; SW - share of surface water; RRI - the number of points of intersection of the road and river networks (see: Table 2). The values of geochemical and ecotoxicological indices were calculated in an Excel spreadsheet, while statistical analyses were performed using the Statistica 13.1 and CANOCO 5.0 programs.

\section{RESULTS AND DISCUSSION}

The content of heavy metals in the bottom sediments of lakes located within the Gniezno Lakeland is presented in Table 4. Based on the average content values in bottom sediments, heavy metals can be arranged in descending order $\mathrm{Zn}>\mathrm{Pb}>\mathrm{Cu}>\mathrm{Cr}>\mathrm{Ni}>\mathrm{Cd}$. A similar sequence of metal content was obtained in studies for the lakes of the Łęczna-Włodawa Lake District by Szafran (2003). The lowest content of $\mathrm{Cr}, \mathrm{Ni}$ and $\mathrm{Pb}$ was found in the bottom sediments of Kierzykowskie Lake, $\mathrm{Cu}$ and $\mathrm{Cd}$ in the sediments of Kamienieckie Lake and $\mathrm{Zn}$ in the sediments of Foluskie Lake. The highest content of $\mathrm{Cr}$ and $\mathrm{Ni}$ was determined in the sediments of Wilczyński Lake and $\mathrm{Cu}, \mathrm{Zn}, \mathrm{Cd}$ and $\mathrm{Pb}$ in the sediments of Ostrówieckie Lake. Among the examined heavy metals, the highest variability in bottom sediments was recorded for $\mathrm{Cu}$ and the lowest for $\mathrm{Ni}$.

Analysis of the CD index shows that bottom sediments of the lakes located in the Gniezno Lakeland are characterized by varied pollution. For most lakes, the pollution index $(\mathrm{CF})$ values remained low or medium (see: Table 5). In most lakes the $\mathrm{Cr}$ and Ni con-

Table 4. Content of heavy metals in the bottom sediments of the lakes $\left(\mathrm{mg} \cdot \mathrm{kg}^{-1}\right)$ on the background of ecotoxicological criteria

\begin{tabular}{rlcccccc}
\hline $\mathrm{Nr}$ & \multicolumn{1}{c}{ Lake } & $\mathrm{Cr}$ & $\mathrm{Ni}$ & $\mathrm{Cu}$ & $\mathrm{Zn}$ & $\mathrm{Cd}$ & $\mathrm{Pb}$ \\
\hline 1 & Foluskie & 5.39 & 3.95 & 7.58 & 22.39 & 0.24 & 14.93 \\
2 & Kamienieckie & 4.95 & 3.66 & 0.40 & 29.34 & 0.14 & 23.63 \\
3 & Kierzkowskie & 3.24 & 2.96 & 5.12 & 25.02 & 0.21 & 14.63 \\
4 & Lednica & 12.05 & 9.21 & 19.96 & 88.76 & 0.92 & $\underline{50.14}$ \\
5 & Niedzięgiel & 11.79 & 8.66 & 2.63 & 71.05 & 0.98 & $\underline{52.57}$ \\
6 & Ostrowskie & 11.79 & 8.56 & 3.07 & 65.92 & 0.76 & $\underline{38.95}$ \\
7 & Ostrówieckie & 17.48 & 15.31 & $\underline{32.86}$ & $\underline{262.00}$ & $\underline{1.89}$ & $\mathbf{8 3 . 4 5}$ \\
8 & Popielewskie & 5.70 & 4.41 & 3.14 & 52.51 & 0.28 & 15.03 \\
9 & Rogoźno & 4.48 & 4.52 & 11.54 & 60.30 & 0.39 & 28.37 \\
10 & Starskie & 5.50 & 4.60 & 13.12 & 42.32 & 0.44 & 21.41 \\
11 & Suszewskie & 5.34 & 4.77 & 4.72 & 34.48 & 0.31 & 18.28 \\
12 & Szydłowskie & 7.08 & 5.48 & 3.10 & 51.82 & 0.23 & 21.76 \\
13 & Tonowskie & 11.46 & 8.45 & 7.51 & 23.58 & 0.18 & 14.85 \\
14 & Wilczyńskie & 22.37 & 16.40 & 7.54 & 103.60 & $\underline{1.27}$ & $\underline{61.78}$ \\
15 & Wolickie & 7.09 & 8.43 & 23.66 & $\underline{205.40}$ & 0.53 & 35.70 \\
16 & Żnińskie Duże & 20.19 & 11.63 & 30.41 & $\underline{155.40}$ & 0.73 & $\underline{44.75}$ \\
\hline & Min-max & $3.24-22.37$ & $2.96-16.40$ & $0.40-32.86$ & $22.39-262$ & $0.14-1.89$ & $14.63-83.45$ \\
& Mean-median & $9.7-7.1$ & $7.6-7.0$ & $11.0-7.5$ & $80.9-56.4$ & $0.6-0.4$ & $33.8-26.0$ \\
& Variablility (\%) & 60.7 & 54.1 & 93.1 & 86.2 & 81.0 & 59.8 \\
\hline
\end{tabular}

Ecotoxicological criteria for assessing the lakes quality using TEC. MEC and PEC values:

$\mathrm{X}$ - level 1, X-level 2, X-level 3, X-level 4 
Table 5. Contamination Factor (CF) values in the bottom sediments of lakes

\begin{tabular}{|c|c|c|c|c|c|c|c|}
\hline $\mathrm{Nr}$ & Lake & $\mathrm{Cr}$ & $\mathrm{Ni}$ & $\mathrm{Cu}$ & $\mathrm{Zn}$ & $\mathrm{Cd}$ & $\mathrm{Pb}$ \\
\hline 1 & Foluskie & $\underline{1.08}$ & 0.79 & $\underline{1.26}$ & 0.47 & 0.47 & $\underline{1.49}$ \\
\hline 2 & Kamienieckie & 0.99 & 0.73 & 0.07 & 0.61 & 0.28 & $\underline{2.36}$ \\
\hline 3 & Kierzkowskie & 0.65 & 0.59 & 0.85 & 0.52 & 0.41 & $\underline{1.46}$ \\
\hline 4 & Lednica & 2.41 & 1.84 & 3.33 & $\underline{1.85}$ & 1.85 & 5.01 \\
\hline 5 & Niedzięgiel & $\underline{2.36}$ & $\underline{1.73}$ & 0.44 & $\underline{1.48}$ & $\underline{1.96}$ & 5.26 \\
\hline 6 & Ostrowskie & 2.36 & 1.71 & 0.51 & 1.37 & 1.52 & 3.90 \\
\hline 7 & Ostrówieckie & 3.50 & 3.06 & 5.48 & 5.46 & $\overline{3.78}$ & $\underline{8.35}$ \\
\hline 8 & Popielewskie & $\underline{1.14}$ & 0.88 & 0.52 & $\underline{1.09}$ & 0.57 & $\underline{1.50}$ \\
\hline 9 & Rogoźno & 0.90 & 0.90 & $\underline{1.92}$ & $\underline{1.26}$ & 0.78 & $\underline{2.84}$ \\
\hline 10 & Starskie & $\underline{1.10}$ & 0.92 & $\underline{2.19}$ & 0.88 & 0.88 & $\underline{2.14}$ \\
\hline 11 & Suszewskie & $\underline{1.07}$ & 0.95 & 0.79 & 0.72 & 0.61 & $\underline{1.83}$ \\
\hline 12 & Szydłowskie & 1.42 & 1.10 & 0.52 & $\underline{1.08}$ & 0.46 & $\underline{2.18}$ \\
\hline 13 & Tonowskie & $\underline{2.29}$ & $\underline{1.69}$ & $\underline{1.25}$ & 0.49 & 0.37 & $\underline{1.49}$ \\
\hline 14 & Wilczyńskie & 4.47 & 3.28 & $\underline{1.26}$ & $\underline{2.16}$ & $\underline{2.54}$ & $\underline{6.18}$ \\
\hline 15 & Wolickie & 1.42 & 1.69 & 3.94 & 4.28 & $\underline{1.06}$ & 3.57 \\
\hline 16 & Żnińskie Duże & 4.04 & $\underline{2.33}$ & 5.07 & 3.24 & 1.46 & 4.48 \\
\hline
\end{tabular}

Bottom sediments pollution: $\mathrm{X}-$ low, $\underline{\mathrm{X}}$ - medium, $\mathrm{X}$ - high, $\underline{\mathrm{X}}$ - very high

tent in the sediments was moderate, while in the lakes Lednica, Ostrówieckie and Żnińskie Duże sediments were significantly polluted. The values of the CF index for $\mathrm{Cu}$ allowed to classify the sediments of four lakes (Lednica, Ostrówieckie, Wolickie and Żnińskie Duże) as significantly contaminated with this element. The sediments of the Ostrówieckie, Wolickie and Żnińskie Duże lakes were significantly contaminated by $\mathrm{Zn}$, while the sediments of the Ostrówieckie Lake by $\mathrm{Cd}$. Sediments in the other lakes were weakly or moderately polluted by $\mathrm{Cu}, \mathrm{Zn}$ and $\mathrm{Cd}$. The values of the $\mathrm{CF}$ index for $\mathrm{Pb}$ for most lakes indicated average sediment pollution, only five lakes were significantly polluted (Lednica, Niedzificationsiel, Ostrowskie, Wolickie, Żnińskie Duży), and the other two highly polluted (Ostrówieckie, Wilczyńskie).

The PLI values ranged from 0.52 (Kamieniecki) to 4.65 (Ostrówieckie), with the mean value being 1.71. The recorded values exceeded the limit value in ten cases (see: Fig. 2a), respectively for lakes: Ostrówieckie (4.65), Żnińskie Duże (3.16), Wilczyńskie (2.93), Lednica (2.51), Wolickie (2.31), Niedzificationsiel (1.74), Ostrowskie (1.60), Rogoźno (1.28),
Starskie (1.24) and Tonowskie (1.05). The MPI also took large values ranging from 2.98 to 26.71 , with a mean of 9.83. The lowest value was observed in Kamieniecki Lake, while the highest in Ostrówieckie Lake (see: Fig. 2b).

According to the ecotoxicological criteria, it was presented that in the 9 lakes heavy metal content in bottom sediments was lower than TEC and were classified to level I. It was found that in bottom sediments of other lakes, the heavy metal affecting the quality assessment was primarily $\mathrm{Pb}$ (6 lakes), Zn (3 lakes), Cd (2 lakes) and $\mathrm{Cu}$ (1 lake). For the bottom sediments of six lakes, the metal content was higher than TEC and lower than MEC: Lednica $\left(\mathrm{Pb}-50.14 \mathrm{mg} \cdot \mathrm{kg}^{-1}\right)$, Niedzięgiel $(\mathrm{Pb}$ - $\left.52.57 \mathrm{mg} \cdot \mathrm{kg}^{-1}\right)$, Ostrowskie $\left(\mathrm{Pb}-38.95 \mathrm{mg} \cdot \mathrm{kg}^{-1}\right)$, Ostrówieckie $\left(\mathrm{Cu}-32.86 \mathrm{mg} \cdot \mathrm{kg}^{-1}, \mathrm{Zn}-262 \mathrm{mg} \cdot \mathrm{kg}^{-1}\right.$, $\left.\mathrm{Cd}-1.89 \mathrm{mg} \cdot \mathrm{kg}^{-1}\right)$, Wilczyńskie $\left(\mathrm{Cd}-1.27 \mathrm{mg} \cdot \mathrm{kg}^{-1}\right.$, $\left.\mathrm{Pb}-61.78 \mathrm{mg} \cdot \mathrm{kg}^{-1}\right)$, Wolickie $\left(\mathrm{Zn}-205.40 \mathrm{mg} \cdot \mathrm{kg}^{-1}\right)$, and Żnińskie Duże $\left(\mathrm{Zn}-155.40 \mathrm{mg} \cdot \mathrm{kg}^{-1}, \mathrm{~Pb}-\right.$ $\left.44.75 \mathrm{mg} \cdot \mathrm{kg}^{-1}\right)$. Due to the fact that the lead content $\left(\mathrm{Pb}-83.45 \mathrm{mg} \cdot \mathrm{kg}^{-1}\right)$ in Ostrówieckie Lake exceeded the MEC value, the bottom sediment pollution of the lake was classified at level III. 

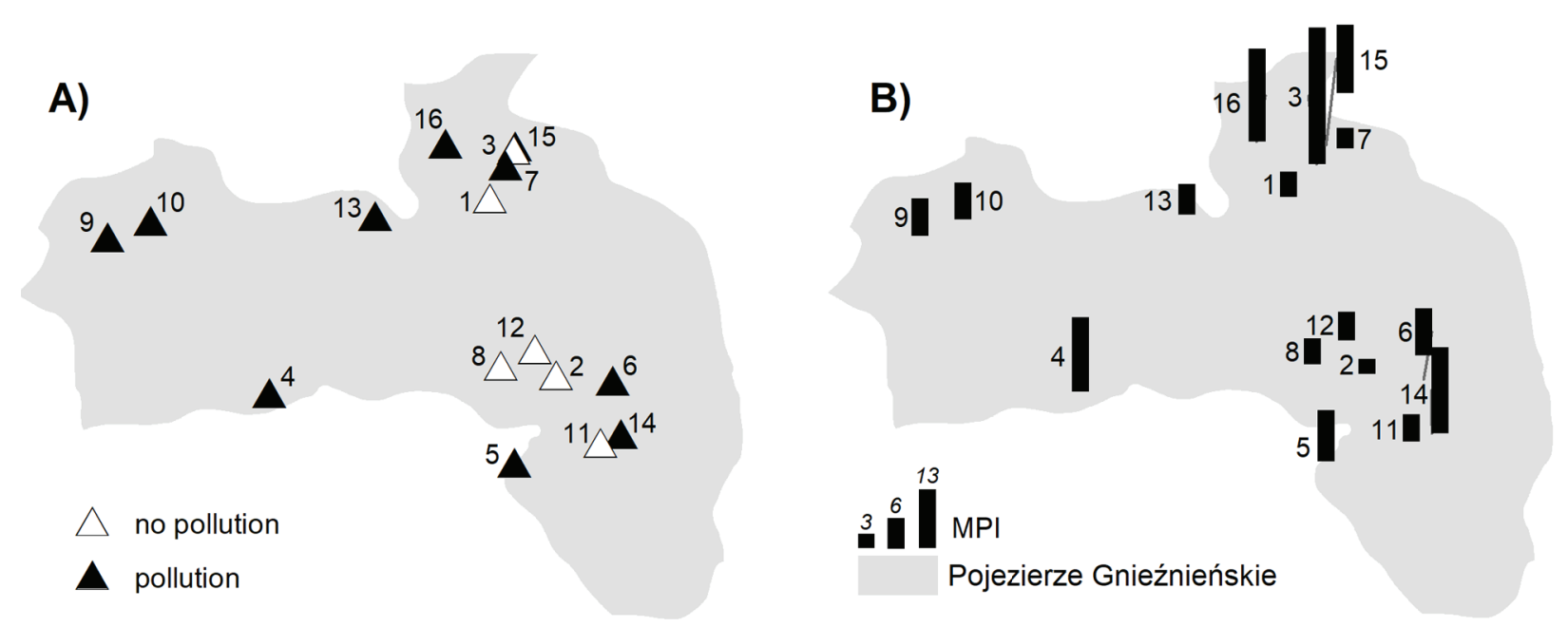

Fig. 2. Classes of (a) Pollution Load Index (PLI) and (b) Metal Pollution Index (MPI) in bottom sediments of lakes

CA analysis allowed to divide the studied lakes into two groups. The first group included Kamienieckie, Kierzkowskie, Popielewskie, Rogoźno, Starskie, Suszewskie, Szydłowskie and Tonowskie lakes, which were characterized by a lower heavy metal content in bottom sediments (see: Fig. 3a). Analysis of heavy metal content in bottom sediments of separate groups using the Mann-Whitney $\mathrm{U}$ test, showed that for $\mathrm{Cr}$, $\mathrm{Ni}, \mathrm{Zn}, \mathrm{Cd}$ and $\mathrm{Pb}$ the differences were statistically significant at the significance level of 0.05 . Only in the case of $\mathrm{Cu}$ the differences were statistically non-significant. The diversity of heavy metal content in bottom sediments of the first group was at a lower level.

Analysis of the main components of PCA allowed the presentation of the content of the examined heavy metals in relation to lake morphometric parameters, total catchments characteristics and the coefficient of water exchange intensity in a lake (see: Fig. 3b). Two main components with eigenvalues greater than 1 were distinguished. $\mathrm{PC} 1$ and $\mathrm{PC} 2$ refer to $73.3 \%$ and $12.4 \%$ of the internal data structure, respectively. The content of $\mathrm{Cr}, \mathrm{Ni}, \mathrm{Zn}, \mathrm{Cd}$ and $\mathrm{Pb}$ was strongly positively correlated with $\mathrm{PC} 1$, while the content of $\mathrm{Cu}$ was less correlated. In addition, a strong correlation of $\mathrm{Cu}$ content with PC2 was demonstrated. It was observed that the $\mathrm{Cu}$ and $\mathrm{Zn}$ content in the bottom sediments of lakes were positively correlated with builtup areas in the catchment area of the studied lakes (BA). Further, heavy metal content was negatively correlated with the shoreline development indicator (SD), which may suggest their supply from areas directly adjacent to the lakes.

The obtained results show that despite the location of the lakes in a relatively small area of the Gniezno Lakeland, the variability of heavy metal content in bottom sediments is high. The content of heavy metals in the bottom sediments of the lakes of the Gniezno Lakeland are at a similar level to those recorded in the Masurian Lakeland (Tylmann et al., 2011), with the exception of $\mathrm{Pb}$, which is almost twice as high. The average content of heavy metals in the bottom sediments of the lakes located in the Gniezno Lakeland is lower compared to the results obtained from the Suwałki Lakeland. The exception is $\mathrm{Pb}$, its content is at a similar level. Compared to lakes located within the Wielkopolski National Park (Sobczyński and Siepak, 2001) heavy metal content is smaller. The functioning of the lakes in national and landscape parks does not provide them a full protection, because pollution comes mainly from the catchment along with waters from the supplying rivers (Choiński and Macias, 2008).

The diversity of heavy metal content in the bottom sediments of lakes stems from diversity of catchment structures and a probable impact of point-type pollution. The analysis of the main components of the PCA did not present evidently those among the examined factors, which are responsible for supplying heavy 

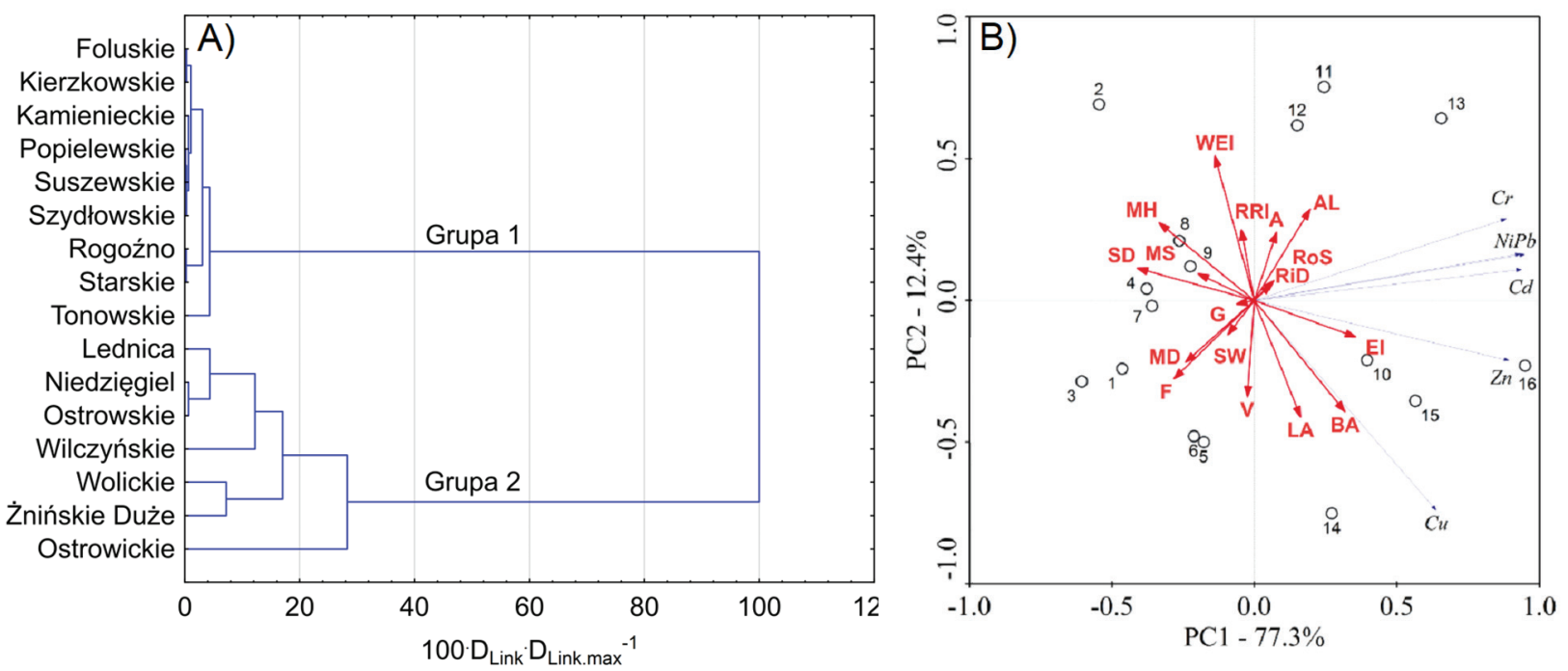

Fig. 3a and 3b. Division of lakes into groups in terms of (A) heavy metals content in bottom sediments and (B) relationships between the characteristics of the lakes and their catchments and the content of heavy metals in bottom sediments (AL - lake area, V - volume, MD - mean depth, SD - shoreline development, EI - exposure index, WEI - water exchange index, A - catchment area, MH - mean height, MS - mean slope, RiD - river network density, RoS - road network density, $\mathrm{AL}$ - arable lands, F - forests, BA - built-up Area, G - grasslands, SW - surface water)

metals to waters. Results obtained by Karwacka et al. (2013) indicate at least partial anthropogenic origin of heavy metals in sediments. The results of the analysis presented in the paper indicate that in order to describe the presence of heavy metals in bottom sediments, the condition of water and sewage management in catchments should be further examined and an analysis of development of areas directly adjacent to lakes or direct catchments should be carried out. In addition, Kuriata-Potasznik et al. (2016) show that the supply of heavy metals may be responsible for the so-called linear sources of pollution, mainly associated with the road network. This research indicates no relationship between road networks and interaction points of road networks and river catchments of the studied lakes and the heavy metal content in bottom sediments.

\section{CONCLUSIONS}

The analysis of heavy metal content in the bottom sediments of lakes located in the Gniezno Lakeland, in relation to morphometric parameters, hydrological conditions and characteristics of direct catchments, allowed to present the following conclusions:
- The diversity of heavy metal content in the bottom sediments of lakes stems from diversity of catchment structures and a probable impact of point-type pollution,

- the bottom sediments of the lakes were heavily polluted with lead, while for other heavy metals, strong pollution was recorded in individual cases,

- lead content in the bottom sediments of individual lakes may cause harmful effects on organisms, while the risk posed by other heavy metals remained at a lower level,

- the lowest content of heavy metals was found in the bottom sediments of Kamieniecki Lake, and the largest in Ostrówieckie Lake,

- the analysis allowed the division of lakes into two groups characterized by a similar content of heavy metals in bottom sediments,

- the research did not isolate clearly the factors that are responsible for the content of heavy metals in the bottom sediments. Therefore, it is necessary to study the condition of water and sewage management in catchments as well as the development of the adjacent areas. 


\section{REFERENCES}

Bojakowska, I., Sokołowska, G. (1998). Geochemiczne klasy czystości osadów wodnych. Przeg. Geolog., 46 (1), 49-54.

Borek, Ł. (2018). Eutrophication risk of water in the manor-park channels: different ways of evaluation. Carpathian Journal of Earth and Environmental Sciences, 13(2), 409-421.

Choiński, A., Macias, A. (2008). Jeziora w parkach narodowych, rezerwatach przyrody i parkach krajobrazowych Polski północnej i środkowej. Wody na obszarach chronionych. Komisja Hydrologiczna PTG, Kraków, 2008, 31-42.

Dąbrowska, J., Moryl, A., Kucharczak-Moryl, E., Żmuda, R., Lejcuś, I. (2016). Zawartość związków azotu w wodach rzeki Strzegomki powyżej zbiornika Dobromierz. Acta Sci. Pol. Form. Cir., 15(3), 57-69.

Dung, T.T.T., Cappuyns, V., Swennen, R., Phung, N. K. (2013). From geochemical background determination to pollution assessment of heavy metals in sediments and soils. Rev. Environ. Sci. Biotechnol., 12(4), 335-353 .

Frankowski, M., Sojka, M., Zioła, A., Siepak, M., Murat -Błażejewska, S. (2009). Distribution of heavy metals in the Mała Wełna River system (western Poland). Oceanol. Hydrobiol. Stud., 38 (2), 51-61.

Glińska-Lewczuk, K., Skwierawski, A., Kobus, Sz., Sidoruk, M., Krzyżaniak, M., (2009). Spatial distribution of heavy metals $(\mathrm{Cr}, \mathrm{Cu}, \mathrm{Zn}$ and $\mathrm{Pb})$ in bottom sediments of oxbow lakes in northern Poland differed by hydrological connectivity. Fresenius Environ. Bull., 18 (7), $1138-1145$.

Główny Inspektorat Ochrony Środowiska (2016). Wyniki badań osadów dennych jezior i zbiorników zaporowych - Państwowy Monitoring Środowiska.

Jahan, S., Strezov, V. (2018). Comparison of pollution indices for the assessment of heavy metals in the sediments of seaports of NSW, Australia. Mar. Pollut. Bull., 128, 295-306.

Jańczak, J. (1996). Atlas jezior Polski: Jeziora Pojezierza Wielkopolskiego i Pomorskiego w granicach dorzecza Odry. Bogucki Wydawnictwo Naukowe.

Joksimovic, D., Castelli, A., Pestoric, B., \& Perosevic, A. (2019). An assessment of trace metal contamination in surface sediments of the montenegrin coast by using pollution indexes and statistical analysis. Fresenius Environ. Bull., 28(2), 879-884.

Karthikeyan, P., Vennila, G., Venkatachalapathy, R. (2018). Assessment of heavy metals in the surface sediments of the Emerald Lake using of spatial distribution and multivariate techniques. Environ. Monit. Assess., 190(11), 668.

Karwacka, A., Niedzielski, P., Staniszewski, R. (2015). Ocena stanu osadów dennych wybranych jezior powiatu poznańskiego. Annual Set The Environment Protection, 17(2), 1684-1698.

Kumar, P., Tasso, J., Guimarães, F., Walfir, P., Souza-filho, M., Powell, M.A., Dall, R. (2019). Catena Statistical analysis of lake sediment geochemical data for understanding surface geological factors and processes: an example from Amazonian upland lakes, Brazil. Catena, 175, 47-62.

Kuriata-Potasznik, A., Szymczyk, S., Skwierawski, A., Glińska-Lewczuk, K., Cymes, I. (2016). Heavy metal contamination in the surface layer of bottom sediments in a flow-through lake: a case study of lake Symsar in Northern Poland. Water, 8(8), 358.

MacDonald, D.D, Ingersoll, C.G, Berger, T.A, (2000b). Consensus-Based Sediment Quality Guidelines, Recommendations for Use \& Application. Interim Guidance. Contaminated Sediment Standing Team, December 2003. Wisconsin Department of Natural Resources.

MacDonald, D.D., Ingersoll, C.G., Berger, T.A. (2000a). Development and evaluation of consensus-based sediment quality guidelines for freshwater ecosystems. Arch. Environ. Contam. Toxicol., 39 (1), 20-31.

Martin, J.M., Meybeck, M., Elemental mass-balance of material carried by major world rivers. Mar. Chem., 7 (3), 173-206.

PN-EN ISO 11885:2009. Water quality - Determination of selected elements by inductively coupled plasma optical emission spectrometry (ICP-OES) (ISO 11885:2007). The Polish Committee for Standardization.

Ptak, M., Sojka, M., Choiński, A., Nowak, B. (2018). Effect of environmental conditions and morphometric parameters on surface water temperature in Polish lakes. Water, 10 (5), 580.

Raut, R., Bajracharya, R.M., Sharma, S., Sharma, C.M. (2017). Potentially toxic trace metals in water and lake-bed sediment of panchpokhari, an alpine lake series in the central himalayan region of Nepal. Water Air Soil Pollut., 228(8), 303.

Siepak, M., Sojka, M. (2017). Application of multivariate statistical approach to identify trace elements sources in surface waters: A case study of Kowalskie and Stare Miasto Reservoir, Poland. Environ. Monit. Assess., 189 (8), 364.

Singovszka, E., Balintova, M., Demcak, S., Pavlikova, P. (2017). Metal pollution indices of bottom sediment and surface water affected by acid mine drainage. Metals, $7(8), 284$ 
Sobczyński, T., Siepak, J. (2001). Speciation of heavy metals in bottom sediments of lakes in the area of Wielkopolski National Park. Pol. J. Environ. Stud., 10 (6), 463-474.

Sojka, M., Jaskuła, J., Siepak, M. (2019a). Heavy metals in bottom sediments of reservoirs in the lowland area of Western Poland: concentrations, distribution, sources and ecological risk. Water, 11(1), 56.

Sojka, M., Jaskuła, J., Wicher-Dysarz, J. (2016). Ocena ładunków związków biogennych wymywanych ze zlewni rzeki Głównej w latach 1996-2009. Annual Set The Environment Protection, 18 (1), 815-830.

Sojka, M., Kałuża, T., Siepak, M., Strzeliński, P., (2019b). Heavy metals concentration in the bottom sediments of the mid-forest reservoirs. Sylwan, 163(8), 694-704.

Sojka, M., Siepak, M., Gnojska, E. (2013). Assessment of heavy metal concentration in bottom sediments of Stare Miasto pre-dam reservoir on the Powa River. Annual Set The Environment Protection. 15(2), 1916-1928.

Sojka, M., Siepak, M., Jaskuła, J., Wicher-Dysarz, J. (2018a). The heavy metals transport in river - reservoir system: a case study of Stare Miasto Reservoir and Powa River, Central Poland. Pol. J. Environ. Stud., 27(4), 1725-1734.

Sojka, M., Siepak, M., Pietrewicz, K. (2018b). Concentration of rare earth elements in surface water and bottom sediments in Lake Wadag, Poland. J. Elem., 24 (1), $125-140$

Sojka, M., Siepak, M., Zioła, A., Frankowski, M., Murat-Błażejewska, S., Siepak, J. (2008). Application of multivariate statistical techniques for evaluation of wa- ter quality in the Mała Wełna River (Western Poland). Environ. Monit. Assess., 147, 159-170.

Szafran, K. (2003). Heavy metals in bottom sediments of three shallow lakes in the Łęczna-Włodawa lakeland. Acta Agrophysica, 1 (2), 329-337.

Szyczewski, P., Siepak, J., Niedzielski, P., Sobczyński, T. (2009). Research on heavy metals in Poland. Pol. J. Environ. Stud., 18(5), 755.

Tomlinson, D.L., Wilson, J.G., Harris, C.R., Jeffrey, D.W. (1980). Problems in the assessment of heavy-metal levels in estuaries and the formation of a pollution index. Helgol. Mar. Res., 33, 566-575.

Tylmann, W., Łysek, K., Kinder, M., Pempkowiak, J. (2011). Regional pattern of heavy metal content in lake sediments in Northeastern Poland." Water Air Soil Pollut., 216(1-4), 217-228.

Wiatkowska, B. (2019). Changes in the flow and quality of water in the dam reservoir of the Mała Panew catchment (South Poland) characterized by multidimensional data analysis. J. Environ. Prot. Sci., 45(1), 26-41.

Yang, Y.M. (2018). Geochemical properties and pollution assessment of heavy metals in the sediments of Daechung Lake, Korea. Environmental Quality Management, 27(4), 163-171.

Zhou, Y., Gao, L., Xu, D., Gao, B. (2019). Science of the Total Environment Geochemical baseline establishment, environmental impact and health risk assessment of vanadium in lake sediments, China. Sci. Total Environ., $660,1338-1345$.

\section{ANALIZA ZAWARTOŚCI METALI CIĘŻKICH W OSADACH DENNYCH JEZIOR POJEZIERZA GNIEŹNIEŃSKIEGO}

\section{ABSTRAKT}

Cel pracy

Celem pracy było wykorzystanie wskaźników geochemicznych i ekotoksykologicznych w ocenie stopnia zanieczyszczania metalami ciężkimi osadów dennych jezior.

\section{Materiat i metody}

Do badań wybrano 16 jezior zlokalizowanych na obszarze Pojezierza Gnieźnieńskiego w centralo-zachodniej Polsce. Dane na temat zawartości metali ciężkich w osadach pochodziły z bazy Państwowego Monitoringu Środowiska. Do oceny stopnia zanieczyszczenia obliczono wskaźnik zanieczyszczenia poszczególnym metalem (CF - Contamination Factor); wskaźnik sumarycznego ładunku zanieczyszczeń metalami (PLI - Polution Load Index) oraz wskaźnik zanieczyszczenia metalami (MPI - Metal Pollution Index). Ocenę potencjalnego działania toksycznego metali ciężkich zakumulowanych w osadach dennych dokonano na podstawie wartości TEC, MEC i PEC. Do wyeksponowania podobieństw pomiędzy jeziorami w zakresie zawartości 
Sojka, M., Jaskuła, J., Wróżyński, R. (2019). Analysis of heavy metals contamination in bottom sediments of lakes located in the Gniezno Lakeland. Acta Sci. Pol., Formatio Circumiectus, 18 (4), 137-149. DOI: http://dx.doi.org/10.15576/ASP.FC/2019.18.4.137

metali ciężkich w osadach dennych, zastosowano analizę skupień (CA). Do identyfikacji czynników kształtujących zawartość metali w osadach dennych oraz potencjalnych źródeł zanieczyszczeń zastosowano analizą składowych głównych (PCA).

\section{Wyniki i wnioski}

Przeprowadzone analizy wykazały duże zróżnicowanie zawartości metali ciężkich w osadach dennych jezior. Najsilniej osady denne jezior zanieczyszczone były ołowiem. Duże zawartości ołowiu w osadach dennych niektórych jezior mogą powodować szkodliwie oddziaływanie na organizmy żywe. Najmniejszą zawartością metali ciężkich charakteryzowały się osady denne jeziora Kamienieckiego, a największą jeziora Ostrówieckiego. Analiza skupień pozwoliła na podział jezior na dwie grupy, charakteryzujące się podobną zawartością metali ciężkich w osadach dennych. Badania nie pozwoliły w sposób jednoznaczny wyeksponować czynników, które odpowiedzialne są za kształtowanie zawartości metali ciężkich w osadach dennych jezior.

Słowa kluczowe: zanieczyszczenie, osady denne, jezioro, ekotoksyczność, indeksy geochemiczne 